\title{
CONGENITAL CYTOMEGALOVIRUS INFECTION IN A NEONATAL INTENSIVE CARE UNIT IN BRAZIL EVALUATED BY PCR AND ASSOCIATION WITH PERINATAL ASPECTS
}

\author{
Daniel Vítor V. SANTOS(1), Maria Margarida R. SOUZA(1), Sérgio Henrique L. GONÇALVES(1), Ana Cristina S. COTTA(1), Lorenza A. O. MELO(2),
} Gláucia M. Q. ANDRADE(2) \& Geraldo BRASILEIRO-FILHO(1)

\begin{abstract}
SUMMARY
Cytomegalovirus (CMV) infection is the most common congenital infection, affecting $0.4 \%$ to $2.3 \%$ newborns. Most of them are asymptomatic at birth, but later $10 \%$ develop handicaps, mainly neurological disturbances. Our aim was to determine the prevalence of CMV shed in urine of newborns from a neonatal intensive care unit using the polymerase chain reaction (PCR) and correlate positive cases to some perinatal aspects. Urine samples obtained at first week of life were processed according to a PCR protocol. Perinatal data were collected retrospectively from medical records. Twenty of the 292 cases $(6.8 \%)$ were CMV-DNA positive. There was no statistical difference between newborns with and without CMV congenital infection concerning birth weight ( $\mathrm{p}=0.11$ ), gestational age $(\mathrm{p}=0.11)$, Apgar scores in the first and fifth minutes of life ( $\mathrm{p}=0.99$ and 0.16$)$, mother's age ( $\mathrm{p}=0.67)$ and gestational history. Moreover, CMV congenital infection was neither related to gender $(\mathrm{p}=0.55)$ nor to low weight $(<2,500 \mathrm{~g})$ at birth $(\mathrm{p}=0.13)$. This high prevalence of CMV congenital infection (6.8\%) could be due to the high sensitivity of PCR technique, the low socioeconomic level of studied population or the severe clinical status of these newborns.
\end{abstract}

KEYWORDS: Cytomegalovirus; Congenital infection; Neonatal Intensive Care Unit (NICU); PCR

\section{INTRODUCTION}

Cytomegalovirus (CMV), a ubiquitous microrganism, is responsible for the most common and widespread congenital infection all over the world, affecting $0.4 \%$ to $2.3 \%$ of all newborns ${ }^{5,20}$. In selected populations such as those infants from neonatal intensive care units (NICU), figures are even larger ${ }^{13}$. Transplacental transmission of CMV may occur either due to maternal primary infection (especially in low prevalence populations) or to recurrent infections (reactivation or reinfection) during pregnancy ${ }^{9,21}$. Previous studies ${ }^{8,12,19,21,23}$ have pointed out that age, race, sexual activity, marital status, parity, socioeconomic background and contact with potential sources of CMV (eg. children in day care centers) are risk factors for delivering a congenitally infected newborn.

Fortunately, most of the infected children do not present signs of the disease at birth or soon thereafter, but up to $10 \%$ may have a severe symptomatic course or even long-term sequelae ranging from discrete learning disabilities to frank hearing loss or other ocular and neurological handicaps ${ }^{1,5,15,20,21}$. The importance of promptly diagnosing CMV infection resides in both the perspectives of intervening therapeutically to minimize morbidity, mortality and sequelae and of determining risk factors for future abnormalities ${ }^{5,20}$.
Classically, the gold standard diagnostic technique for congenital CMV infection has been viral isolation in urine, although usually only serology is available in daily practice, with its obvious limitations ${ }^{3,10}$. Alternative approaches have emerged, of which the polymerase chain reaction (PCR) is especially promising for its high sensitivity, specificity and relative simplicity $2,3,6,7,24,25$.

In Brazil, studies have shown that prevalence of $\operatorname{IgG}$ antibodies to CMV in pregnant women range from $66.5 \%$ to $92 \%$ depending on the applied technique (enzyme linked immune assay or complement-fixing reaction, usually higher in the later $)^{11}$ and on the social background of the studied population (low or middle socioeconomical level, higher in the former) ${ }^{14,22}$. Concerning congenital CMV infection assessed by viral isolation, its prevalence rates have been found to range from $0.46 \%$ and $0.92 \%$ in low and middle socioeconomical level populations respectively ${ }^{14}$. Recently, there has also been a report on the use of the PCR versus viral isolation in congenital and perinatal CMV infection ${ }^{25}$, but prevalence studies in neonatal intensive care units applying this technique are still lacking in Brazil.

Our study aimed at using this novel technique so as to determine the prevalence of congenital CMV infection in a selected population of

Financial support: FAPEMIG

(1) Departamento de Anatomia Patológica e Medicina Legal da Faculdade de Medicina da Universidade Federal de Minas Gerais, Belo Horizonte, MG, Brasil

(2) Departamento de Pediatria da Faculdade de Medicina da Universidade Federal de Minas Gerais, Belo Horizonte, MG, Brasil

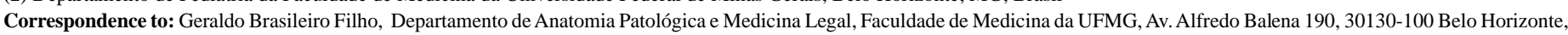
MG, Brasil; E-mail: gbrasil@medicina.ufmg.br 


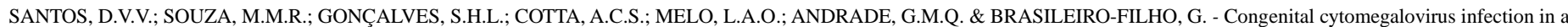
neonatal intensive care unit in Brazil evaluated by PCR and association with perinatal aspects. Rev. Inst. Med. trop. S. Paulo, 42(3): 129-132, 2000.

infants in a NICU unit from a university hospital and to relate it to some perinatal findings.

\section{PATIENTS AND METHODS}

From 1995 to 1998, we studied 292 newborns from Hospital das Clínicas da Universidade Federal de Minas Gerais (HC-UFMG) selected at random, all of them from the NICU. Urine sample from each newborn was collected in the first week of life and stored in a freezer until processed.

PCR was performed using two pairs of primers that anneal to wellconserved immediate early (IE) and late (LA) transcripted regions of CMV genome leading to amplification of 393 and 139 bp fragments, respectively (Table 1$)$.

From two milliliters of urine collected, $1 \mathrm{~mL}$ was used for stock and $1 \mathrm{~mL}$ for DNA extraction. The latter consisted of centrifugation at 5,000 rpm for 15 minutes followed by discharge of the supernatant and suspension of the pellet (urine sediment) in $200 \mu \mathrm{L}$ of PCR buffer $(2.5 \mathrm{~mL}$ $\mathrm{KCl} 2 \mathrm{M}, 1 \mathrm{~mL}$ Tris- $\mathrm{HCl} 1 \mathrm{M} \mathrm{pH} 8,250 \mu \mathrm{L} \mathrm{MgCl}_{2} 1 \mathrm{M}, 10 \mathrm{mg}$ gelatin, $450 \mu \mathrm{L} \mathrm{NP}_{40}, 450 \mu \mathrm{L}$ Tween 20 and $\mathrm{H}_{2} \mathrm{O}$ q.s.p. $100 \mathrm{~mL}$ ). Six microliters of proteinase $\mathrm{K}$ solution $(20 \mathrm{mg} / \mathrm{mL})$ were then added and incubated at $52{ }^{\circ} \mathrm{C}$ for two hours. Finally, the enzyme was inactivated by boiling at $100{ }^{\circ} \mathrm{C}$ for seven minutes. Reaction mixture consisted of $3 \mu \mathrm{L}$ of the former DNA suspension, $2.5 \mu \mathrm{L}$ of $10 \mathrm{X}$ PCR buffer $\left(15 \mathrm{mM} \mathrm{MgCl}_{2}, 500\right.$ $\mathrm{mM} \mathrm{KCl}, 100 \mathrm{mM}$ Tris- $\mathrm{HCl} \mathrm{pH=8),} 6$ pmol of each of the four deoxynucleotide triphosphates, 0.75 IU of Taq DNA polymerase, 20 pmol of each primer and deionized water to get a final volume of $25 \mu \mathrm{L}$. DNA amplification was performed in a MJ Research MiniCycler ${ }^{\mathrm{TM}}$ (initial five-minute-denaturation at $94{ }^{\circ} \mathrm{C}$, two-minute-annealing and extension at $72{ }^{\circ} \mathrm{C}$ followed by 34 cycles of thirty-second-denaturation at $94{ }^{\circ} \mathrm{C}$ and two-minute-annealing and extension at $72{ }^{\circ} \mathrm{C}$, at the end of the programme, a seven-minute-final-extension at $72^{\circ} \mathrm{C}$ ). All amplification reactions contained a positive (one microliter of extracted CMV DNA from positive urine) and negative ( $3 \mu \mathrm{L}$ of deionized water) controls. Products were submitted to electrophoresis and analyzed in silver-stained $6 \%$ polyacrilamide gels ${ }^{16}$.

Congenital CMV infection was defined as amplification of CMV DNA by either or both IE and LA primers in urine collected in the first week of life. All positive cases were confirmed in a second test.

Data on the newborns and their mothers were collected retrospectively from livebirth declaration forms ("Declaração de Nascidos Vivos" - DNV), "Centro Latinoamericano de Perinatalogia" (CLAP-

OPS/OMS) perinatal clinical history forms and medical records. Unfortunately, not all data were accessible for all patients due to incomplete and/or inadequate filling of the available records. Variables were considered suitable for statistical analysis when they were missing in less than $5 \%$ of the patients.

Statistical analysis were performed in Epi Info Software ${ }^{4}$ using Chisquare or Fisher (comparison of frequencies), ANOVA (comparison of means) and Kruskal-Wallis (comparison of medians) tests, depending on the data profile and distribution. $\mathrm{P}$ value was considered statistically significant when $\leq 0.05$.

\section{RESULTS}

During the study interval, 292 newborns had urine samples analyzed: 179 males $(61.3 \%)$ and 113 females (38.7\%). Mean gestational age, weight, stature and cephalic perimeter at birth were respectively $35.3 \pm 2.8$ weeks (median: 35 weeks), 2,226 $\pm 751 \mathrm{~g}$ (median: $2,100 \mathrm{~g}$ ), $44.4 \pm 4.1 \mathrm{~cm}$ (median: $44.5 \mathrm{~cm}$ ) and $32.1 \pm 3.5 \mathrm{~cm}$ (median: $32 \mathrm{~cm}$ ). Apgar scores at one and five minutes showed respective mean values of $6.5 \pm 2.5$ (median: 8 ) and $8.4 \pm 1.2$ (median: 9). Mean hospital stay was $22.0 \pm 23.8$ days (median: 14 days). Mothers had a mean age of $26.9 \pm 6.9$ years (median: 26 years), most of them were married or had a stable union (73.2\%) and had only elementary education $(72.4 \%)$. Their gestational history showed a mean of 1.4 deliveries (median: 1 delivery) and 0.3 miscarriage (median: no miscarriage).

Among the 292 newborns, 20 (6.8\%) showed CMV-DNA in urine during their first week of life, indicating congenital infection (Table 2). In ten newborns, only LA primers yielded DNA amplification; in seven both LA and IE did so and in the remaining three newborns, only target DNA for IE primers was amplified.

Data loss did not differ when analyzing the frequency of CMV-DNA positive and negative subjects among those whose variables where available and those whose variables were missing.

Variables with less than 5\% loss were analyzed (Table 2). Comparing non-infected versus $\mathrm{CMV}$ infected newborns, mean weight did not differ $(2,245 \pm 748 \mathrm{~g}$ versus $1,967 \pm 763 \mathrm{~g} ; \mathrm{p}=0.11)$, so as gestational age medians ( 35 weeks versus 35 weeks; $\mathrm{p}=0.11$ ). One and five-minute-Apgar scores showed similar medians in the two groups $(\mathrm{p}=0.99$ and $\mathrm{p}=0.16$ ) (Table $2)$. Low birth weight $(<2500 \mathrm{~g})$ and normal birth weight $(\geq 2500 \mathrm{~g})$ were not statistically related to CMV congenital infection $(\mathrm{p}=0.13)$. There were also no gender differences concerning CMV infection $(\mathrm{p}=0.55)$ (Table 2).

Table 1

Primers used in the polymerase chain reaction

\begin{tabular}{lccc}
\hline \multicolumn{1}{c}{ Primer } & Sequence & Product size & Target region \\
\hline LA1 (upstream) & 5' CCG CAA CCT GGT GCC CAT GG 3' & 139bp & gp64 late antigen † \\
LA2 (downstream) & 5' CGT TTG GGT TGC GCA GCG GG 3' & \\
\hline IE1 (upstream) & 5' GCT GCG GCA TAG AAT CAA GGA GCA C 3' & 393bp & immediate early $\$$ \\
IE2 (downstream) & 5' GGT TGG TGG TCT TAG GGA AGG CTG AG 3' & gene \\
\hline
\end{tabular}

$\dagger$ : SHIBATA et al, 1988; $\neq$ : BORG et al., 1995 
Mother's age was slightly higher in CMV infected newborns (medians: 28.5 versus 26 years), although not statistically significant $(\mathrm{p}=0.67)$. A similar situation was observed when comparing both groups concerning parity $(p=0.25)$ and number of miscarriages $(p=0.51)$ (Table 2$)$.

\section{DISCUSSION}

In Brazil, studies applying polymerase chain reaction in the diagnosis of CMV congenital infection are still scarce ${ }^{25}$, especially those dealing with prevalence in a significant number of newborns and specifically in a neonatal intensive care unit. In this regard, we are adding important data to the knowledge of this subject. Moreover, we tried to correlate CMV congenital infection with some features linked to the infants and their mothers. In this analysis, it is essential to bear in mind that since previous maternal serological status was not available, we could be assessing not only factors influencing transplacental infection but also maternal infection ${ }^{12}$.

Despite the high prevalence of congenital CMV infection in our investigation $(6.8 \%)$, values up to $10 \%$ have been described when studying infants from NICU elsewhere using the PCR ${ }^{13}$. The low socioeconomical level of the studied population and, mainly, the clinical status of the newborns (from a NICU) possibly influenced the high prevalence rate of congenital CMV infection now described as compared with that of the general population.

It is established that in populations with unfavourable socioeconomical conditions congenital CMV infection is more prevalent ${ }^{14,21}$. Besides, the expected number of infected newborns among those in worse clinical conditions is higher than in the general population, once the deleterious effects determined by the virus begin in the fetus. Finally the high sensitivity of the applied technique may have contributed towards a higher detection of congenital infection ${ }^{13,25}$. However, if from one side PCR improves sensitivity, from the other one must be aware of the risk of false positive results, essentially through contamination. So we tried to attenuate this risk performing DNA extraction, amplification and electophoresis phases in separated rooms, using positive and negative controls and making a second corfirmatory PCR test in all positive cases in the first reaction.

It is known that some variables are related to a higher or lower risk of delivering a CMV congenitally infected newborn ${ }^{8,12,19,21,23}$. In this studied population, we could not detect any difference between the group with and without congenital CMV infection concerning the analyzed maternal data (Table 2). Congenital CMV infection is a established cause of intrauterine growth restriction (IUGR). However, in our sample, birth weight was not different between infected and non-infected newborns $(1,967 \pm 763 \mathrm{~g}$ versus $2,245 \pm 748 \mathrm{~g} ; \mathrm{p}=0.11)$. This finding may possibly be related to the profile of the newborns, since most of them, coming from the NICU, were affected by fetal or maternal diseases that cause IUGR. An analogous interpretation can be made concerning gestational age in these patients (medians: 35 versus 35 weeks; $p=0.11$ ), once there were other prevalent causes of prematurity in this population. Apgar scores did also not differ between the two groups, as other maternal aspects like age and gestational history.

Infected infants are being followed periodically by the infectologist staff of HC-UFMG. In the first visit, CMV serology, a skull x-ray and/ or a transfontanel ultrasound and a fundoscopic examination are performed. The infant is then followed clinically in intervals of three months until two years old, when an audiometry test is performed. After that, the child is examined anually so as to evaluate his/her development.

In our experience, PCR technique showed to be useful and effective in the early diagnosis of congenital CMV infection.

Table 2

Comparison between newborns with and without congenital cytomegalovirus infection from a university hospital neonatal intensive care unit

\begin{tabular}{|c|c|c|c|c|}
\hline \multirow[b]{2}{*}{ Variable } & \multicolumn{2}{|c|}{ Mean/median/frequency } & \multirow[b]{2}{*}{ Missing data } & \multirow[b]{2}{*}{$\mathrm{p}$-value } \\
\hline & $\begin{array}{c}\text { CMV(+)group } \\
(\mathrm{n}=20)\end{array}$ & $\begin{array}{l}\text { CMV(-)group } \\
\quad(n=272)\end{array}$ & & \\
\hline \multicolumn{5}{|l|}{ Newborn } \\
\hline Birth weight $(\mathrm{g}$, mean $\pm \mathrm{SD})$ & $1,967 \pm 763$ & $2,245 \pm 748$ & $0 \%$ & $0.11 \dagger$ \\
\hline Low $\quad(<2500 g)$ & $17(85 \%)$ & $188(69.1 \%)$ & $0 \%$ & $0.13 \phi$ \\
\hline Normal $(\geq 2500 \mathrm{~g})$ & $3(15 \%)$ & $84(30.9 \%)$ & & \\
\hline Gender & & & $0 \%$ & $0.55 \phi$ \\
\hline Male & $11(55 \%)$ & $168(61.8 \%)$ & & \\
\hline Female & $9(45 \%)$ & $104(38.2 \%)$ & & \\
\hline Gestational age (weeks, median) & 35 & 35 & $1.7 \%$ & $0.11 \ddagger$ \\
\hline Apgar score at 1' (median) & 8 & 8 & $2.1 \%$ & 0.99 \\
\hline Apgar score at 5' (median) & 9 & 9 & $1 \%$ & 0.16 \\
\hline \multicolumn{5}{|l|}{ Mother } \\
\hline Mother's age (years, median) & 28.5 & 26 & $0.7 \%$ & $0.67 \ddagger$ \\
\hline No. of deliveries (median) & 1 & 1 & $3.8 \%$ & 0.25 \\
\hline No. of miscarriages (median) & 0 & 0 & $3.8 \%$ & $0.51 \%$ \\
\hline
\end{tabular}

SD: standard deviation; $\uparrow$ : ANOVA between CMV(+) and CMV(-) groups; $\phi$ : Chi-square test between CMV(+) and CMV(-) groups; $\$$ : Kruskal-Wallis H test between $\mathrm{CMV}(+)$ and $\mathrm{CMV}(-)$ groups 
SANTOS, D.V.V.; SOUZA, M.M.R.; GONÇALVES, S.H.L.; COTTA, A.C.S.; MELO, L.A.O.; ANDRADE, G.M.Q. \& BRASILEIRO-FILHO, G. - Congenital cytomegalovirus infection in a neonatal intensive care unit in Brazil evaluated by PCR and association with perinatal aspects. Rev. Inst. Med. trop. S. Paulo, 42(3): 129-132, 2000.

\section{ACKNOWLEDGEMENTS}

To Professor Eugênio Marcos Andrade Goulart, for his statistical support and reviewing of the manuscript.

\section{RESUMO}

\section{Infecção congênita pelo citomegalovírus em unidade neonatal de alto risco de um hospital universitário no Brasil: prevalência avaliada pela PCR e associação com alguns aspectos perinatais}

A citomegalovirose é das infecções congênitas mais prevalentes, acometendo de $0,4 \%$ a $2,3 \%$ dos nascidos vivos. A maioria dos recémnascidos (RN) infectados é assintomática, mas até $10 \%$ desenvolvem seqüelas variadas, principalmente neurossensoriais. Objetivamos determinar a prevalência do CMV na urina de RN através da PCR, correlacionando-a a alguns achados perinatais. Analisamos amostras de urina colhidas na $1^{\text {a }}$ semana de vida de $292 \mathrm{RN}$ do HC-UFMG, todos internados na unidade neonatal de alto risco. DNA viral foi amplificado segundo protocolo de PCR. Os dados perinatais foram colhidos retrospectivamente de registros médicos. Na população estudada, 20 dos 292 casos $(6,8 \%)$ mostraram positividade para o DNA-CMV. Não houve diferença estatisticamente significante entre os RN com e os sem infecção congênita pelo CMV quanto a peso ao nascer $(\mathrm{p}=0,11)$, idade gestacional $(\mathrm{p}=0,11)$, índice de Apgar no $1^{\circ}$ e $5^{\circ}$ minutos $(\mathrm{p}=0,99$ e 0,16$)$, idade da mãe $(\mathrm{p}=0,67)$ e história gestacional materna. Também não se observou associação da infecção congênita pelo CMV com baixo peso ao nascer $(\mathrm{p}=0,13)$ ou sexo do $\mathrm{RN}(\mathrm{p}=0,55)$. A alta prevalência da infecção congênita neste estudo $(6,8 \%)$ pode ser devida à elevada sensibilidade da PCR, ao baixo nível sócio-econômico da população estudada ou às características clínicas mais graves desses RN.

\section{REFERENCES}

1. BOPPANA, S.B.; PASS, R.F.; BRITT, W.J.; STAGNO, S. \& ALFORD, C.A. Symptomatic congenital cytomegalovirus infection: neonatal morbidity and mortality. Pediat. infect. Dis. J., 11: 93-99, 1992.

2. BORG, K.L.; NORDBO, A.S.; WINGE, P. \& DALEN, A. - Detection of cytomegalovirus using "boosted" nested PCR. Molec. cell. Probes, 9: 251-257, 1995.

3. CHOU, S. - Newer methods for diagnosis of cytomegalovirus infection. Rev. infect. Dis., 12 (suppl. 7): S727-S736, 1990.

4. DEAN, A.G.; DEAN, J.A.; COULOMBIER, D. et al. - Epi Info, Version 6: a Word processing, database and statistics program for Epidemiology on microcomputers. Atlanta, Centers for Disease Control and Prevention, 1994.

5. DEMMLER, G.J. - Summary of a workshop on surveillance for congenital cytomegalovirus disease. Rev. infect. Dis., 13: 315-329, 1991.

6. DEMMLER, G.J.; BUFFONE, G.J.; SCHIMBOR, C.M. \& MAY, R.A. - Detection of cytomegalovirus in urine from newborns by using polymerase chain reaction DNA amplification. J. infect. Dis., 158: 1177-1184, 1988.

7. EHRNST, A. - The clinical relevance of different laboratory tests in CMV diagnosis. Scand. J. infect. Dis., 100 (suppl.): 64-71, 1996.

8. FOWLER, K.B. \& PASS, R.F. - Sexually transmitted diseases in mothers of neonates with congenital cytomegalovirus infection. J. infect. Dis., 164: 259-264, 1991.
9. GRUNDY, J.E. - Virologic and pathogenetic aspects of cytomegalovirus infection. Rev. infect. Dis., 12 (suppl. 7): S711-S719, 1990.

10. LANDINI, M.P. - New aproaches and perspectives in cytomegalovirus diagnosis. Progr. med. Virol., 40: 74-81, 1993.

11. MAGALHÃES-NETO, J.M.; NOGUEIRA, F.E.; SILVA, J.F. et al. - Prevalência de anticorpos para citomegalovírus em gestantes em Salvador - Bahia. Folha méd., 106: 55-57, 1993.

12. MURPH, J.R.; SOUZA, I.E.; DAWSON, J.D et al. - Epidemiology of congenital cytomegalovirus infection: maternal risk factors and molecular analysis of cytomegalovirus strains. Amer. J. Epidem., 147: 940-947, 1998.

13. ODA, K.; OKI, S.; TSUMURA, N. et al. - Detection of cytomegalovirus DNA in urine from newborns in NICU using a polymerase chain reaction. Kurume med. J., 42: 39-44, 1995

14. PANNUTI, C.S.; VILAS-BOAS, L.S.; ANGELO, M.J.O.; CARVALHO, R.P.S. \& SEGRE, C.M. - Congenital cytomegalovirus infection. Occurrence in two socioeconomically distinct populations of a developing country. Rev. Inst. Med. trop. S. Paulo, 27: 105-107, 1985.

15. PASS, R.F.; STAGNO, S.; MYERS, G.J. \& ALFORD, C.A. - Outcome of symptomatic congenital cytomegalovirus infection: results of long-term longitudinal follow-up. Pediatrics, 66: 758-762, 1980.

16. SANTOS, F.R.; PENA, S.D.J. \& EPPLEN, J.T. - Genetic and population study of a Ylinked tetranucleotide repeat DNA polymorphism with a simple non-isotopic technique. Hum. Genet., 90: 655-656, 1993.

17. SHIBATA, D. - Detection of human cytomegalovirus. In: INNIS, M.A.; GELFAND, D.H.; SNINSKYEDS, J.J. et al., ed. PCR protocols: a guide to methods and applications. San Diego, Academic Press, 1990. p 368-371.

18. SHIBATA, D.; MARTIN, W.J. \& APPLEMAN, M.D. - Detection of cytomegalovirus DNA in peripheral blood of patients infected with human immunodeficiency virus. J. infect. Dis., 158: 1185-1192, 1988.

19. SOHN, Y.M.; OH, M.K.; BARCAREK, K.B.; CLOUD, G.A. \& PASS, R.F. Cytomegalovirus infection in sexually active adolescents. J. infect. Dis., 163: 460 463, 1991 .

20. STAGNO, S. - Cytomegalovirus. In: REMINGTON, J.S. \& KLEIN, J.O., ed. Infectious diseases of the fetus and the newborn infant. 4. ed. Philadelphia, WB Saunders, 1995.

21. STAGNO, S.; PASS, R.F.; CLOUD, G.A. et al. - Primary cytomegalovirus infection: incidence, transmission to the fetus, and clinical outcome. J. Amer. med. Ass., 256: 1904-1908, 1986.

22. SUASSUNA, J.H.R.; LEITE, L.L. \& VILLELA, L.H.C. - Prevalence of cytomegalovirus infection in different patient groups of a urban university in Brazil. Rev. Soc. bras. Med. trop., 28: 105-108, 1995.

23. TOOKEY, P.A.; ADES, A.E. \& PECKHAM, C.S. - Cytomegalovirus prevalence in pregnant women: the influence of parity. Arch. Dis. Childh., 67: 779-783, 1992.

24. XU, W.; SUNDQVIST, A.; BRYTTING, M. \& LINDE, A. - Diagnosis of cytomegalovirus infections using polymerase chain reaction, virus isolation and serology. Scand. J. infect. Dis., 25: 311-316, 1993.

25. YAMAMOTO, A.Y.; AQUINO, V.H.; FIGUEIREDO, L.T.M. \& MUSSI-PINHATA, M.M. - Diagnosis of congenital and perinatal cytomegalovirus infection by using the polymerase chain reaction. Rev. Soc. bras. Med. trop., 31: 19-26, 1998.

Received: 27 October 1999

Accepted: 20 January 2000 